\title{
Study OF InkJet Prints Properties
}

\author{
Sindic, I.; DoBric, E.; BOlANCA MirKovic, I. \& BOlANCA, Z.
}

Abstract: Ink Jet is the printing technology which uses droplets of ink without any contact with the printing substrate. The droplets are sprayed through the nozzles on the substrate to create the image. In this work the research results of the influence of different Ink Jet printing technologies (thermal one, piezoelectric technique) on the characteristics and the durability of the prints have been presented. The dyes and pigment dispersion have been used and the matt paper as the printing substrate as well. The research results show increased dot values on prints obtained by using the pigment dispersion in relation to the dye with the application of the mentioned substrates. The presentation of the two dimensional and three dimensional model gamut of the observed samples in CIE $L^{*} a * b^{*}$ colour space confirms the previously mentioned supposition. The durability of prints in the controlled environmental conditions has also been discussed.

Key words: Ink Jet, pigment based ink, dye based ink, mat substrate, screen value, colour gamut, durability
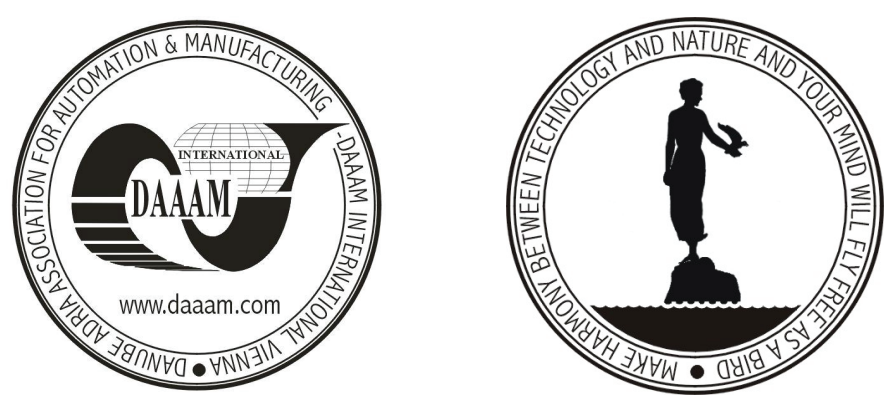

Authors' data: BSc. Sindic I.[gor]*, BSc. Dobric E.[ugen]*, MSc. Bolanca Mirkovic I.[vana]**, PhD. Prof. Bolanca Z.[denka]**, Europapress Holding*, Faculty of Graphic Arts, University of Zagreb**, Croatia, igors@metro.com.hr, e_dobric@yahoo.com, grfibolanca@yahoo.com, zbolanca@yahoo.com

This Publication has to be referred as: Sindic, I.; Dobric, E.; Bolanca Mirkovic, I. \& Bolanca, Z. (2006). Study of Inkjet Prints Properties, Chapter 45 in DAAAM International Scientific Book 2006, B. Katalinic (Ed.), Published by DAAAM International, ISBN 3-901509-47-X, ISSN 1726-9687, Vienna, Austria

DOI: $10.2507 /$ daaam.scibook.2006.45 